\title{
Epidemiology and treatment of uncomplicated gonorrhoea caused by non-PPNG strains in Córdoba, Argentina: auxotypes, susceptibility profiles, and plasmid analyses of urethral isolates from men
}

\author{
H K MONAYAR,* A LEDESMA, $†$ V NOBILE, $\ddagger$ J A VIARENGO \\ From the *Venereal Disease Division, $\nmid$ Department of Epidemiology, $\ddagger$ Microbiology Department, and the \\ $\S$ Direction of Preventive Medicine, Public Health Ministry, Córdoba, Argentina
}

SUMMARY The official records of uncomplicated gonorrhoea for Córdoba state show that between 1975 and 1985, about one in 1000 sexually active people acquired gonorrhoea each year. A study was therefore undertaken to obtain information about treatment of uncomplicated gonorrhoea, as well as the nutritional requirements, plasmid analyses, and susceptibility profiles of gonococci in this geographical area.

From August 1983 to April 1984, 219 men with uncomplicated gonorrhoea were treated with one of four antibiotic schedules, all of which were over $95 \%$ efficient. All 98 strains isolated and purified were non-penicillinase-producing Neisseria gonorrhoeae (non-PPNG). The minimum inhibitory concentrations (MICs) of benzylpenicillin, tetracycline, thiamphenicol, spectinomycin, kanamycin, and cefoxitin were assessed. The MIC of benzylpenicillin showed that $88 \%$ (86) of the strains were inhibited by $0.5 \mathrm{mg} / \mathrm{l}$ of the drug, and also showed a bimodal sensitivity pattern to that antibiotic. The nutritional requirements of the 62 strains tested showed that $53 \%$ (33) were of the nonrequiring (wild type) auxotype, $42 \%(26)$ required proline (pro ${ }^{-}$) and $5 \%$ (3) required proline and arginine ( pro $^{-} \mathrm{arg}^{-}$). Resistance to antibiotics was more notable in the pro ${ }^{-}$than in the wild type strains.

In the past 25 years, the prevalence of strains of $\mathrm{Nei-}$ sseria gonorrhoeae showing resistance to penicillin has increased. The increasing minimum inhibitory concentrations of penicillin and other antimicrobials during this time reflects the increased incidence and resistance of the strains, which was not the result of $\beta$ lactamase production. ${ }^{1-3}$

Strains of penicillinase producing $N$ gonorrhoeae (PPNG) were isolated for the first time in 1976 in the United States and United Kingdom, but have now been found in many other countries. ${ }^{4-7}$ In the present study we assessed the results of treatment of 219 men with uncomplicated gonorrhoea caused by non-PPNG strains who attended the Venereal Dis-

Address for reprints: Dr J A Viarengo, Roque R Peña 158, 2434-Arroyito-Córdoba, Argentina.

Accepted for publication 14 December 1986 ease Division of the Public Health Ministry of Córdoba, Argentina (a state clinic for treating sexually transmitted diseases) in 1983-84. We also investigated the nutritional requirements, $\beta$ lactamase activity, and susceptibility profiles of several of the strains isolated and undertook plasmid analysis of several strains.

\section{Patients, materials, and methods}

Urethral material was collected from men with uncomplicated gonorrhoea who attended the clinic from August 1983 to April 1984. $N$ gonorrhoeae was identified by Gram stained smear microscopy of the exudates, the oxidase reaction, and the ability of isolates to produce acid from glucose, but not from lactose, maltose, or sucrose. Isolates from patients were cultured on modified Thayer-Martin medium, and for further subculture we used GC medium base enriched 
with $1 \%$ haemoglobin and $1 \%$ IsoVitalex without added antibiotics. We examined the $\beta$ lactamase activity of the gonococcal isolates on primary culture by the chromogenic cephalosporin $87 / 312$ test. $^{89}$ Patients were treated with one of four treatment schedules: ampicillin $3.5 \mathrm{~g}$ as a single oral dose, doxycycline $100 \mathrm{mg}$ by mouth every 12 hours for five days, thiamphenicol $2.5 \mathrm{~g}$ as a single oral dose, or spectinomycin $2.0 \mathrm{~g}$ by a single intramuscular injection. After treatment, all patients were required to return within three to five days for follow up.

The following criteria were used to evaluate the results of treatment: if diplococci were absent in Gram stained smears and follow up culture gave a negative result, the treatment was considered successful; if diplococci were absent and culture gave negative results, but more than 10 pus cells per high power field ( $\times 100$ objective) were found in the urethral smear, postgonococcal urethritis (PGU) was diagnosed. In patients who did not return for follow up, treatment was considered to have been successful.

If diplococci were present in Gram stained smears, or follow up culture for $\mathrm{N}$ gonorrhoeae gave a positive result, treatment was assumed to have failed.

\section{ANTIBIOTIC SUSCEPTIBILITY TEST}

Minimum inhibitory concentrations (MICs) were measured by the agar dilution method using diagnostic sensitivity test (DST) agar (Oxoid) with $1 \%$ haemoglobin and $1 \%$ IsoVitalex. The inoculum was prepared from the growth of an 18-24 hour subculture resuspended in brain heart infusion by means of an electric mixer (vortex). The suspension was adjusted, by photometric comparison, to a turbidity equal to McFarland standard No 1 (about $10^{8}$ colony forming units $\left.(\mathrm{cfu} / \mathrm{ml})\right)$. Before measuring the MIC with a replicating device, the suspension was diluted $1 / 100$. The replicator delivered $0.001-0.002 \mathrm{ml}$ of inoculum, resulting in about $10^{3}-10^{4} \mathrm{cfu}$ of organisms per inoculum spot.

Six antimicrobial agents were tested in $\log _{2}$ dilution steps: benzylpenicillin 0.007 to $64 \mathrm{mg} / 1$, tetracycline 0.06 to $4 \mathrm{mg} / \mathrm{l}$, thiamphenicol 0.25 to $4 \mathrm{mg} / \mathrm{l}$, spectinomycin 1 to $32 \mathrm{mg} / \mathrm{l}$, kanamycin 1 to $32 \mathrm{mg} / \mathrm{l}$, and cefoxitin 0.006 to $8 \mathrm{mg} / \mathrm{l}$.

The WHO-A, WHO-B, WHO-C, and WHO-D strains of $N$ gonorrhoeae were used as control strains.

\section{AUXOTYPING}

The auxotypes of 62 strains of $N$ gonorrhoeae were identified by growing them on standard neisseria defined agar (NEDA) medium with $0.1 \%$ soluble starch. To prepare the media and the standardised gonococcal suspensions, we used the methods described by Catlin and Pace. ${ }^{10} 11$ All media were inoculated with $10^{3}$ to $10^{4} \mathrm{cfu}$ delivered by Steers replicating apparatus, and were incubated at $35-36^{\circ} \mathrm{C}$ in air plus $3-5 \%$ carbon dioxide.

Growth response was considered to be positive if macrocolonies were present and numerous, and negative if there were five or fewer macrocolonies. All strains isolated were positive on complete NEDA medium and negative on medium without cysteine.

To correlate the auxotypes of the 62 strains tested with their resistance to antibiotics, they were tested further against the following concentrations of drugs: $0.25 \mathrm{mg} / \mathrm{l}$ benzylpenicillin, $1.0 \mathrm{mg} / \mathrm{l}$ tetracycline, $0.75 \mathrm{mg} / 1$ thiamphenicol, and $6 \mathrm{mg} / 1$ spectinomycin.

\section{PLASMID ANALYSIS}

We examined the plasmid content of 54 strains of $N$ gonorrhoeae using the method of Birnboim and Doly. ${ }^{12}$ The harvest of growth from one Petri dish with GC agar base medium plus $1 \%$ IsoVitalex was suspended in $1 \mathrm{ml}$ physiological saline and, after being centrifuged at $15000 \mathrm{~g}$ for 20 seconds, the cells were resuspended in $200 \mu \mathrm{l}$ of solution I. Birnboim and Doly's method was followed throughout, except that all volumes were doubled.

The gel for electrophoresis was made using 0.9\% agarose (Sigma No A6877, Type II: medium EEO (electroendosmosis)). Electrophoresis was carried out at room temperature until the dye was $10-15 \mathrm{~mm}$ from the bottom of the gel. The gel was then placed in a solution of ethidium bromide $(0.05 \mathrm{mg} / \mathrm{l})$, stained for 15 minutes, ${ }^{1314}$ and then examined under ultraviolet light on a black background.

Of the reference strains of $N$ gonorrhoeae, WHO-E and WHO- 4 both contained the 2.6 megadalton cryptic plasmid, WHO-E also contained the 3.2 megadalton plasmid, whereas WHO-4 also contained the 4.5 and 24.5 megadalton plasmids.

\section{Results}

The official register of uncomplicated gonorrhoea in the state of Córdoba shows that in 1975-85 about one in 1000 people acquired the disease each year. Three quarters of the total number of patients were reported from the capital, and the remaining quarter from the other cities of the state (table 1).

In this study 219 men with uncomplicated gonorrhoea, aged 15 to 47, were examined during September 1983 to April 1984. Of the $48(22 \%)$ treated with ampicillin, two $(4 \%)$ were treatment failures and three $(6 \%)$ developed PGU. Of the $56(26 \%)$ treated with thiamphenicol, one ( $2 \%$ ) was a treatment failure and two $(4 \%)$ developed PGU. Of the $54(25 \%)$ patients treated with doxycycline, none were treatment failures and two (4\%) developed PGU. Of the 61 $(28 \%)$ patients treated with spectinomycin, two $(3 \%)$ were treatment failures and three $(5 \%)$ developed PGU. ${ }^{15}$ 
Table 1 Uncomplicated gonorrhoea in Córdoba State, Argentina, 1975-85

\begin{tabular}{|c|c|c|c|c|c|}
\hline Year & Population & No of patients & $\begin{array}{l}\text { Incidence per } \\
10000 \text { population }\end{array}$ & $\begin{array}{l}\text { No (\%) from } \\
\text { capital }\end{array}$ & $\begin{array}{l}\text { No (\%) from } \\
\text { other cities }\end{array}$ \\
\hline $\begin{array}{l}1975 \\
1976 \\
1977 \\
1978 \\
1979 \\
1980 \\
1981 \\
1982 \\
1983 \\
1984 \\
1985\end{array}$ & $\begin{array}{l}2240561 \\
2273 \quad 875 \\
2307 \quad 190 \\
2340504 \\
2373819 \\
2407134 \\
2445 \quad 167 \\
2483 \quad 199 \\
2521 \quad 233 \\
2559266 \\
2597 \quad 299\end{array}$ & $\begin{array}{l}1885 \\
2575 \\
2437 \\
2400 \\
2114 \\
1538 \\
1854 \\
2186 \\
3248 \\
2579 \\
2094\end{array}$ & $\begin{array}{r}84 \\
113 \\
106 \\
103 \\
89 \\
64 \\
76 \\
88 \\
129 \\
101 \\
81\end{array}$ & $\begin{array}{l}1338(71) \\
1931(75) \\
1828(75) \\
1872(78) \\
1628(77) \\
1123(73) \\
1279(69) \\
1443(66) \\
2339(72) \\
1857(72) \\
1633(78)\end{array}$ & $\begin{array}{l}547(29) \\
644(25) \\
609(25) \\
528(22) \\
486(23) \\
415(27) \\
575(31) \\
743(34) \\
909(28) \\
722(28) \\
461(22)\end{array}$ \\
\hline
\end{tabular}

Total area of the state $=168766 \mathrm{sq} \mathrm{km}$. Area of capital $=562 \mathrm{sq} \mathrm{km}$.

Table 2 Minimum inhibitory concentrations of six antimicrobial agents for 98 non-penicillinase-producing strains of Neisseria gonorrhoeae isolated in Córdoba, Argentina, 1983-84

\begin{tabular}{|c|c|c|c|c|c|c|c|c|c|c|c|c|c|}
\hline \multirow[b]{2}{*}{ Antimicrobial agents } & \multicolumn{13}{|c|}{ Cumulative \% of strains sensitive to $\mathrm{mg} / \mathrm{l}$} \\
\hline & 0.007 & 0.015 & 0.03 & 0.06 & $0 \cdot 12$ & 0.25 & 0.5 & 1 & 2 & 4 & 8 & 16 & 32 \\
\hline $\begin{array}{l}\text { Benzylpenicillin } \\
\text { Tetracycline } \\
\text { Thiamphenicol } \\
\text { Spectinomycin } \\
\text { Kanamycin } \\
\text { Cefoxitin }\end{array}$ & 8 & 24 & 37 & $\begin{array}{l}39 \\
3^{*}\end{array}$ & $\begin{array}{r}58 \\
3\end{array}$ & $\begin{array}{c}69 \\
12 \\
2^{*}\end{array}$ & $\begin{array}{l}88 \\
12 \\
14\end{array}$ & $\begin{array}{r}92 \\
43 \\
100\end{array}$ & $\begin{array}{r}100 \\
96\end{array}$ & $\begin{array}{l}100 \\
15^{*}\end{array}$ & $\begin{array}{c}100 \\
20^{*}\end{array}$ & 83 & 100 \\
\hline
\end{tabular}

*These concentrations or lower.

Table 2 shows the MICs of six antibiotics against 98 non-PPNG strains tested. The MICs of benzylpenicillin ranged from $0.007 \mathrm{mg} / 1$ to $2 \mathrm{mg} / 1$ for this unselected group of strains and showed two peaks, one at $0.015 \mathrm{mg} / \mathrm{l}$ and the other at $0.25 \mathrm{mg} / \mathrm{l}$.

Plasmid analysis showed that of the 54 strains tested, $45(83 \%)$ had a 2.6 megadalton cryptic plasmid only, and nine $(17 \%)$ also contained the 24.5 megadalton transfer plasmid. PPNG strains were not detected in this study.

Of the 98 strains of $N$ gonorrhoeae, 62 were studied for nutritional requirements. Table 3 shows that 33 $(53 \%)$ belonged to the non-requiring (wild) auxotype, $26(42 \%)$ were $\mathrm{pro}^{-}$, and three $(5 \%)$ were $\mathrm{pro}^{-} \mathrm{arg}^{-}$.

Table 4 shows that of the 33 non-requiring strains, $10(30 \%)$ were resistant to $0.25 \mathrm{mg} / \mathrm{l}$ benzylpenicillin, $12(36 \%)$ were resistant to $1.0 \mathrm{mg} / \mathrm{l}$ tetracycline, eight $(24 \%)$ were resistant to $0.75 \mathrm{mg} / 1$ thiamphenicol, and $18(55 \%)$ were resistant to $6 \mathrm{mg} / \mathrm{l}$ spectinomycin. Of the pro ${ }^{-}$strains, nine $(35 \%)$ were resistant to $0.25 \mathrm{mg} / \mathrm{l}$ benzylpenicillin, $14(54 \%)$ to $1.0 \mathrm{mg} / 1$ tetracycline, $12(46 \%)$ to $0.75 \mathrm{mg} / 1$ thiamphenicol, and $13(50 \%)$ to $6 \mathrm{mg} / \mathrm{l}$ spectinomycin.

\section{Discussion}

This study presents preliminary data on uncomplicated gonorrhoea and infecting strains of gono-
Table 3 Auxotypes of 62 non-penicillinase-producing strains of Neisseria gonorrhoeae isolated in Córdoba, Argentina, 1983-84

\begin{tabular}{lcc}
\hline Auxotype & No & (\% of total) \\
\hline Non-requiring & 33 & $(53)$ \\
Proline requiring & 26 & $(42)$ \\
Proline and Arginine requiring & 3 & $(5)$ \\
\hline
\end{tabular}

cocci in our geographical area. As it is difficult to achieve a reasonable follow up rate for treatment or evaluation, it is especially important to ensure complete and effective treatment at the initial visit, and we therefore propose three simple treatment schedules.

A review of the epidemiology of uncomplicated gonorrhoea in Córdoba state, found that in 1975-85 the official incidence of this disease had variations that may have correlated with the socioeconomic changes in this area. We found that the prevalence of susceptible strains of $N$ gonorrhoeae was high, and the results of treating the 219 men who had gonorrhoea showed that the four regimens were more than $95 \%$ effective. The 98 non-PPNG strains tested in this study showed a bimodal pattern of sensitivity to benzylpenicillin and reflected the increase in resistance to penicillin seen in venereal disease clinics. ${ }^{16}$ The MIC of benzylpenicillin showed that almost $90 \%$ of these strains required $0.5 \mathrm{mg} / 1$ to be 
Table 4 Resistance to specific concentrations of four antibiotics in 62 strains of Neisseria gonorrhoeae of three auxotypes

\begin{tabular}{llll}
\hline & No $) \%$ of strains of auxotype & \\
\cline { 2 - 4 } Antibiotic & $\begin{array}{l}\text { Non-requiring } \\
(n=33)\end{array}$ & $\begin{array}{l}\text { Proline requiring } \\
(n=26)\end{array}$ & $\begin{array}{l}\text { Proline and arginine requiring } \\
(n=3)\end{array}$ \\
\hline Benzylpenicillin $0.25 \mathrm{mg} / 1$ & $10(30)$ & $9(35)$ & 0 \\
Tetracycline $1 \mathrm{mg} / 1$ & $12(36)$ & $14(54)$ & $1(33)$ \\
Thiamphenicol $0.75 \mathrm{mg} / 1$ & $8(24)$ & $12(46)$ & $1(33)$ \\
Spectinomycin $6 \mathrm{mg} / \mathrm{l}$ & $18(55)$ & $13(50)$ & 0 \\
\hline
\end{tabular}

inhibited. The 98 strains isolated were tested for $\beta$ lactamase activity, and all gave negative results. This finding agreed with the results of plasmid analysis; the 54 strains studied contained the cryptic 2.6 megadalton plasmid, and nine of them also contained the 24.5 megadalton transfer plasmid.

The study of the nuritional requirements of $62 \mathrm{~N}$ gonorrhoeae strains showed that more than half were of non-requiring auxotypes. To establish the relation between auxotype and sensitivity to four antibiotics, we undertook a further test of resistance to specific quantities of antibiotics in the agar plates. The numbers of strains that resisted the specific concentration of the four drugs showed differences in susceptibility to antibiotics between the auxotype groups.

In conclusion, we understand that the number of strains tested was relatively small, but if we compare the non-requiring and pro $^{-}$auxotypes groups, pro $^{-}$ strains were more resistant than non-requiring strains. Correlation between the strains tested and those from other areas in Argentina cannot be made because publications on this subject are not available.

We thank Drs Inga Lind and Karin Reimann for the recommendations on plasmid analysis and for providing us with reference strains of $N$ gonorrhoeae.

\section{References}

1 Petzoldt D, Gründer K, Neubert U. Sensitivity of Neisseria gonorrhoeae to penicillin in West Germany. British Journal of Venereal Diseases 1979;55:80-2.

2 Gründer K, Petzoldt D. Sensitivity of Neisseria gonorrhoeae to spectinomycin and thiamphenicol. British Journal of Venereal
Diseases 1980;56:252-4.

3 Martin JE, Lester A, Price EV, Schnde JD. Comparative study of gonococcal susceptibility to penicillin in the United States 1955-1969. J Infect Ds 1970;122:459-61.

4 Jaffe HW, Biddle JW, Johnson SR, Wiesner PJ. Infections due to penicillinase producing Neisseria gonorrhoeae in the United States, 1976-1980. J Infect Dis 1981;144:191-7.

5 Arya OP, Rees E, Percival A, Allergant CD, Annels EH, Turner GC. Epidemiology and treatment of gonorrhoea caused by penicillinase-producing strains in Liverpool. British Journal of Venereal Diseases 1978;54:28-35.

6 Piot P. Resistant gonococcus from the Ivory Coast. Lancet 1977;i:857.

7 Bijkerk H. Penicillinase producing gonococci in the Netherlands. British Journal of Venereal Diseases 1980;56:243.

8 Thornsberry C. Technical improvement service. Am J Clin Pathol 1976;25:79-84.

9 Thornsberry C. Rapid laboratory test for $\beta$-lactamase production by bacteria. Atlanta, Georgia: US Department of Health, Education, and Welfare, 1977.

10 Catlin BW, Pace PJ. Auxotypes and penicillin susceptibility of Neisseria gonorrhoeae isolated from patients with gonorrhoea involving two or more sites. Antimicrob Agents Chemother 1977;12:147-57.

11 Catlin BW. Characteristic and auxotyping of Neisseria gonorrhoeae. In: Bergan T, Norris JR, eds. Methods in microbiology. Vol 10. London: Academic Press, 1978:345-80.

12 Birnboim HC, Doly J. A rapid alkaline extraction procedure for screening recombinant plasmid DNA. Nucleic Acids Res 1979;7:1513-23.

13 Mickel S, Arena V, Bauer LS. Physical properties and gel electrophoresis behavior of RIZ-derived plasmid DNAs. Nucleic Acids Res 1977;4:1465-82.

14 Foster R, Foster G. Electrophoretic comparison of endonuclease digested plasmid from Neisseria gonorrhoeae. J Bacteriol 1976;126:1297-304.

15 Guinan ME, Biddle J, Thornsberry C, Reynolds G, Zaidi A, Wiesner $P$. The national gonorrhoeae therapy monitoring study. I. Review of treatment results and of in-vitro antibiotic susceptibility, 1972-1978. Sex Transm Dis 1979;6 suppl:93-102.

16 Willcox RR. A world wide view of venereal disease. British Journal of Venereal Diseases 1972;46:163-76. 